\title{
Integrated Management of Common Bacterial Blight (Xanthomonas axonopodis pv. Phaseoli) of Common Bean (Phaseolus vulgaries) in Kaffa, Southwest Ethiopia
}

\author{
Kifle Belachew $^{1 *}$, Mebratu Gebremariam ${ }^{2}$, Kumlachew Alemu ${ }^{3}$ \\ ${ }^{1}$ EIAR, Jimma Agricultural Research Center, Crop Protection Department, P.O.Box 192, Jimma, ETHIOPIA \\ ${ }^{2}$ SARI, Bonga Agricultural Research Center, P.O. Box 101, Kaffa, ETHIOPIA \\ ${ }^{3}$ Department of Plant Science, Assosa University, P.O.Box 18, Assosa, ETHIOPIA \\ *Correspondence (Email): \\ kiflekef@gmail.com
}

\begin{abstract}
This study was conducted to determine the effect of integrated management of common bacterial blight (Xanthomonas axopodai) of bean on disease development, yield and yield components. A field experiment was conducted at Chena district Dahera peasant association on farmers training center field during 2011/2012 main cropping season using four resistant common bean cultivars and one susceptible local check. Host resistance was integrated with seed treatment using Apron $2 \mathrm{~g} / \mathrm{kg}$ and cultural practice. The experiment was arranged in randomized complete block design in factorial combination with three replications. The results indicate that integrating of resistant varieties with chemical seed treatment and cultural practice were highly significant $(\mathrm{p}<0.001)$ in reducing common bacterial blight development and increased seed yield and yield component of a bean. The highest percent severity index of common bacterial blight $(71.95 \%)$ was observed in the control treatment when growing of local cultivar under farmer management practice. This level was reduced significantly to below $26 \%$ when planting chemically treated seed of the cultivars Awassa dumme, AFR-702 and Ibado on the ridges, with an average yield of more than $22 \mathrm{qt} / \mathrm{ha}$. Generally, integrating host resistance with seed treatment and cultural practice could reduce the severity of common bacterial blight and increase yield and yield component of the bean. However, an extensive similar study should be conducted across different locations to come with a tangible recommendation.
\end{abstract}

Key words: Common bacteria blight, Common bean, Host resistance, seed treatment

\section{INTRODUCTION}

Common bean (Phaseolus vulgaris L.) is one of the most important legumes worldwide because of its high commercial value, extensive production, consumer use and nutrient values (Popovic et al., 2012). Economic significance of common bean in Ethiopia is quite considerable since it represents one of the major food and cash crops. It has a great potential for the country as it has been dully recognized by many researchers and organization for its economic importance and its domestic demands for various uses. Production of this crop is indispensable in the country to enrich the stable cereal crop with sufficient and high quality protein in order to overcome the problem of malnutrition (Tadesse et al., 2009). Under the optimal management conditions, productivity of common bean can reach to 2.5 to 3.0 ton per hectare in Ethiopia (Amare, 1987). However, the actual average production from 2008 to 2010 production year is only 1.4 ton per hectare (ICRISAT, 2011) which is very far from the potential yield of the crop. The major production constraints of common beans include moisture stress, diseases, insect pest, weeds, poor soil fertility and lack of improved seeds (Kidane, 1987; Ayele, 1991). Of which, diseases are known to be the major factors which threatened the productivity of 
common bean in all growing area (Fininsa, 2001; Abiy et al., 2006; Tadesse et al., 2009). Among many diseases affecting common bean, Root rot (Fusarium oxysporum), common bacterial blight (CBB), caused by Xanthomonas axonopodis pv. Phaseoli and halo blight caused by Pseudomonas syringae pv. phaseolicola are the most destructive diseases of beans worldwide (Ariyaratne et al., 1998; Dursun et al., 2002). Among which, common bacterial blight disease is recognized as economically important disease of bean (Popovic et al., 2012).

Common bacterial blight is a worldwide problem in bean production and highly destructive during extended periods of warm and humid weather, resulting in yield and seed quality losses. The disease can attack leaves, stems, pods, seeds, and reported to causes considerable yield loss (Fininsa, 2001; Fourie, 2002). The average yield loss due to common bacterial blight is estimated to range from 10 to $40 \%$, it may reach $100 \%$ depending on the intensity of the disease, degree of bean susceptibility and environmental conditions that favor the progress of the disease (Opio et al., 1996). In Ethiopia also, common bacterial blight is reported as the main constraints to common bean production throughout the country (Tadesse et al., 2009).

The best alternatives for managing CBB of bean includes, use of healthy, pathogen-free seed, crop rotation, and plowing of infected straw (Suchuster and Coyne, 1981). Planting of bean cultivars resistant to Xanthomonas axonopodis is economically and technically the most practical method for effective management of CBB (Popovic et al., 2012). Nowadays, integrated disease management is the preferred strategy because of increased understanding on residual effects of chemical control on non target organisms and environment as well as the limitation of a single alternative management option to achieve the same level of control and reliability as that of chemicals.

Use of resistant varieties supplemented with chemical seed treatment and proper cultural practices could be the best alternative options in managing common bacterial blight of common bean and avoiding yield losses. However, there is no empirical research data on the effect of integrated disease management of common bacterial blight of bean using host resistance, cultural practice and application of seed treatment to control the disease in Ethiopia. Thus, this study was conducted to determine the effect of integrated management of common bacterial blight on disease development, yield and yield components of common bean.

\section{Materials AND Methods}

\section{Description of the Study area}

The study was conducted at Southern Nations and Nationalities and Peoples region of Ethiopia, Kaffa zone, Chena district Dahera peasant association on farmers training center field during 2011/12 main cropping season. The area is located at $07^{\circ} 18^{\prime} 48^{\prime \prime} \mathrm{N}$ Latitude and $036^{\circ} 16^{\prime} 25^{\prime \prime}$ E Longitude and at altitude of 2020 m.a.s.l. The area experiences one long rainy season, lasting from March to October. The mean annual rainfall ranges from $1710 \mathrm{~mm}$ to $2000 \mathrm{~mm}$. Over $85 \%$ of the total annual rainfall, with mean monthly values in the range of 125 to $250 \mathrm{~mm}$ occurs in the 8 months long rainy season. The mean temperature ranges from $18.1^{\circ} \mathrm{C}$ to $21.4^{\circ} \mathrm{C}$. Environmentally the site is belongs to the sub-agro ecology tepid to midland and comprising of mixed arable farming and woodland, including much relict primary tropical forest. The soil of the study area is sandy clay loam at the top and sandy clay at sub soil characterized as dystric nitosol with $\mathrm{pH}$ of 5.4. The topography is characterized by slopping and rugged areas with very little plain land (Cherinet, 2008; Tilahun M. and Kifle B., 2015).

\section{Experimental Materials and Treatments \\ Plant materials}

Four improved common bean cultivars obtained from Awassa agricultural research center and Melkasa agricultural research center, and one local check were used as host resistance components of the treatment. The cultivars were Ibado, Awassa-Dumme, Omo-95, AFR-702 and one local check. These cultivars were the most adapted and widely grown common bean types around the study area.

\section{Treatment}

Four disease management strategies including, row planting on ridges, chemical seed treatment (with Apron $2 \mathrm{~g} / \mathrm{kg}$ seeds ) and row planting on flat field, row planting on ridges and chemical seed treatment and farmers practice (simply broad casting on the field) were used in the experiment.

\section{Experimental Design}

The treatments were arranged in, 5 varieties $\times 4$ disease management practice in randomized complete block design (RCBD) with factorial combination, forming a total of 20 treatment combinations including the control. Each treatment in the experiment was replicated three times. Spacing between blocks measured $2 \mathrm{~m}$, and between adjacent plots $1.5 \mathrm{~m}$. Each plot has a size of $1.6 \mathrm{~m} \times 4 \mathrm{~m}$ and contained four rows (with two harvestable central rows) of the bean plants. A spacing of $40 \mathrm{~cm}$ between rows and $10 \mathrm{~cm}$ between plants were uniformly adopted along with recommended cultural practices for all treatments. 


\section{Data Collection}

Data on disease incidence and severity were collected from ten randomly selected plants from the two central rows of each plot. Disease incidence was calculated as the percentage of plants showing disease symptoms. Data on disease severity was recorded as percentage of leaf area covered by lesions. Disease severity was scored using standard disease scales of 1-9 (CIAT, 1998), were 1 stands for approximately $5 \%$ infection; $2=15 \%, 3=25 \%, 6=65 \%, 8=75 \%$ and $9=85 \%$. The severity grades were then converted into percentage severity index (PSI) for analysis (Wheeler, 1969).

$$
\text { PSI }=\frac{\text { Snr }}{\text { Npr } \times \text { Mss }} \times 100
$$

Where $\mathrm{Snr}=$ the sum of numerical ratings, $\mathrm{Npr}=$ number of plant rated, Mss $=$ the maximum score of the scale.

\section{Assessment of Yield and Yield Component}

The number of pod per plant and seed per pod were recorded from 10 randomly selected and tagged plants in the middle two rows of each plot. Ten pods from each selected plant were taken and seeds from each pod were counted and recorded. Bean yield data were taken at $10 \%$ moisture content after adjustment using moisture tester. Mean yield data was calculated by converting the yield obtained from harvested two middle rows in each plot into hectare and weight of 100 randomly selected seed was also measured.

\section{Data Analysis}

The data were subjected to analysis of variance (ANOVA) using the general linear model (GLM) of SAS statistical software version 9.2 and mean comparisons were made using Least significant difference (LSD) at 0.05 probability level.

\section{RESULTS AND Discussion}

\section{Effect of Integrated Management on Disease Incidence}

Use of resistant cultivars combined with chemical seed treatment and cultural practice alone or in combination significantly $(\mathrm{p}<0.001)$ reduced incidence of common bacterial blight of bean (Table 01$)$. The highest bacterial blight incidence $(100 \%)$ was recorded from plot receiving local cultivar treated with all management practices, and also when farmer growing practices are combined with all common bean cultivars with no significance difference with the former treatment. The level of diseases incidence was reduced significantly to below $51 \%$ when chemically treated seed of improved cultivars Ibado, Awassa dumme, Omo- 95 and AFR-702 were planted on the ridges. From all cultivars used for this experiment, Ibado recorded least diseases incidence $(66.95 \%)$, while local cultivar shows the highest diseases incidence (97.2\%). Moreover, combined management practice via chemical seed treatment plus planting on ridges significantly reduced diseases incidence $(57.15 \%)$ than untreated farmers practice $(96.58 \%)$. Chemical seed treatment alone significantly reduce diseases incidence in improved common bean cultivars $(<68 \%)$ than other treatments (Table 01). Present study showed that, chemical seed treatment combined with improved haricot bean cultivar and planting on the ridges showed good potential in reducing diseases incidence of common bacterial blight of bean

Table 01: Effect of the combined application of treatment on diseases incidence of common bacterial blight of bean

\begin{tabular}{llllll}
\hline Treatment & \multicolumn{4}{c}{ Haricot bean Cultivars } \\
\cline { 2 - 6 } & Ibado & $\begin{array}{l}\text { Awassa } \\
\text { dumme }\end{array}$ & Omo-95 & AFR-702 & Local \\
\hline Planting on ridges & $70.03^{\mathrm{de}}$ & $84.03^{\mathrm{bc}}$ & $84.83^{\mathrm{bc}}$ & $78.47^{\mathrm{cd}}$ & $100^{\mathrm{a}}$ \\
Chemical seed treatment & $60.33^{\mathrm{fg}}$ & $66.97^{\mathrm{ef}}$ & $67.87^{\mathrm{ef}}$ & $63.63^{\mathrm{ef}}$ & $100^{\mathrm{a}}$ \\
$\begin{array}{l}\text { Planting on ridges }+ \\
\text { chemical seed treatment }\end{array}$ & $46.0^{\mathrm{h}}$ & $50.87^{\mathrm{hg}}$ & $50.87^{\mathrm{hg}}$ & $46.83^{\mathrm{h}}$ & $91.20^{\mathrm{ab}}$ \\
Farmers practice & $91.5^{\mathrm{ab}}$ & $97.30^{\mathrm{a}}$ & $97.30^{\mathrm{a}}$ & $96.80^{\mathrm{a}}$ & $100^{\mathrm{a}}$ \\
\hline CV (\%) & & & & 7.50 \\
LSD (0.05) & & & & 9.57 \\
\hline
\end{tabular}

Values are means of three replications, and means followed by the same letter do not differ significantly at $\mathrm{P}<0.05$

\section{Effect of Integrated Management on Disease Severity}

Results of the present study reviled that, integrating resistant varieties with chemical seed treatment and cultural practice significantly $(\mathrm{p}<0.001)$ reduced severity of common bacterial blight of bean (Table 02$)$. The highest present severity index $(71.95 \%)$ was observed in the control treatment when local cultivar is grown under framer practice. This level was reduced significantly to below $24 \%$ by planting chemically treated seed of the cultivars Ibado and AFR-702 on the ridges. This is at par with planting of chemically treated seeds of the cultivars of Awassa dumme and Omo-95 on ridges. 
Table 02: Effect of the combined application of treatment on disease severity of common bacterial blight of bean

\begin{tabular}{lllllc}
\hline Treatment & \multicolumn{4}{c}{ Haricot bean Cultivars } \\
\cline { 2 - 5 } & Ibado & $\begin{array}{c}\text { Awassa } \\
\text { dumme }\end{array}$ & Omo-95 & AFR-702 & Local \\
\hline Planting on ridges & $36.53^{\text {ghi }}$ & $42.03^{\mathrm{fg}}$ & $42.47^{\mathrm{efg}}$ & $39.23^{\mathrm{gh}}$ & $64.16^{\mathrm{b}}$ \\
Chemical seed treatment & $30.13^{\mathrm{jkl}}$ & $33.47^{\mathrm{hij}}$ & $33.97^{\mathrm{hij}}$ & $31.82^{\mathrm{ijk}}$ & $55.67^{\mathrm{c}}$ \\
Planting on ridges + & & & & & \\
chemical seed treatment & $23.01^{\mathrm{m}}$ & $25.83^{\mathrm{klm}}$ & $25.47^{\mathrm{lm}}$ & $23.43^{\mathrm{m}}$ & $45.63^{\mathrm{def}}$ \\
Farmers practice & $45.77^{\mathrm{def}}$ & $50.33^{\mathrm{cd}}$ & $50.71^{\mathrm{cd}}$ & $48.60^{\mathrm{de}}$ & $71.95^{\mathrm{a}}$ \\
\hline CV $(\%)$ & & & & & 9.27 \\
LSD (0.05) & & & & & 6.27 \\
\hline
\end{tabular}

Values are means of three replications and means followed by the same letter do not differ significantly at $\mathrm{P}<0.05$

Present study showed that, the cultivars Ibado and AFR-702 recorded least diseases severity $(<36 \%)$, while local cultivar shows the highest diseases severity $(59.35 \%)$. Moreover, combined management practice (i.e. chemical seed treatment plus planting on ridges) significantly reduced diseases severity $(23.67 \%)$ than farmers' practice $(53.47 \%)$ in all cultivars. It is also found that chemical seed treatment alone significantly reduces diseases severity in improved common bean cultivars $(<37 \%)$ than the control treatments via planting of local cultivar under farmer management practice. Since, the main predisposing factor for transmission of the diseases is infected seeds, seed treatment plays a significant role in reducing development of common bacterial blight by reducing the initial inoculum of the pathogen (Schaad et al. 1995; Yu et al. 1998).

The present study results provides empirical evidences that use of integration of resistant variety with other management strategies via chemical seed treatment and planting on the ridges reduces disease development significantly. The effectiveness of host resistance as the sole method of controlling common bacterial blight has been reported to be low when compared to that of synthetic fungicides. However, the efficacy of host resistance can be improved by manipulation of the environment and integration with other methods of control including chemical seed treatment (Ebrahim et al., 2009). It was also reported that relatively resistant cultivars can effectively control CBB when used as components of integrated disease managements (Mutlu et al., 2005). Present result indicate that, the cultivar Ibado and AFR-702 reduced development of common bacterial blight considerably when they are combined with chemical seed treatment and cultural practice via planting on the ridge. The use of raised ridges to grow beans has been found to reduce severity of diseases that are favored by high moisture (CIAT, 1992). This is because ridging can increase aeration and drainage, creating less favorable conditions for disease development (Nzungize et al., 2012). Similar to the present study, combination of host resistance with available options of diseases management could reduce the amount of yield losses caused by prevalent disease (Shtienberg et al., 206; Ebrahim et al., 2009).

\section{Effect of Integrated Management of Common Bacterial Blight on Yield and Yield Component of Common Bean \\ Seed yield}

Analysis of variance indicates that, there was a highly significant $(\mathrm{P}<0.001)$ difference among treatment on grain yield of bean (Table 03). Higher seed yield was observed in Awassa dumme and AFR-702 varieties when their seed is treated chemically accompanied by planting on the ridges with an average yield of $25.48 \mathrm{qt} / \mathrm{ha}$ and $25.47 \mathrm{qt} / \mathrm{ha}$, respectively. Planting of chemically treated seed of the cultivar Awassa dumme on flat land also showed good potential (24.42qt/ha) in the experiment, with no statistical different with the former treatments. On the other hand, the lowest yield (10.44 qt/ha) was observed on the control treatment when local cultivars are grown under farmer management practices. The present study indicate that, when resistance varieties are integrated with chemical seed treatment and planting on ridge influence the level of disease epidemic and amount of yield loss attributed to CBB. Relatively resistant variety, Awassa dumme and AFR-702, had reduced CBB development and increased seed yield. The increase yield suggests that the crop sustain considerable loss of photosynthetic tissue without affecting the amount of storage carbohydrate translocated to developing pods and seeds. Similar to the present study, combination of host resistance with available options of disease management increased grain yield of bean (Shtienberg et al., 206; Ebrahim et al., 2009).

\section{Yield components}

Integrating of resistant cultivars with chemical seed treatment and cultural practice, significantly $(\mathrm{p}<0.001)$ affect number of pods per plant, seeds per pod and hundred seed weight of bean (Table 03). Higher number of pod was recorded on planting of chemically treated seed of the cultivar Awassa dumme (25.48) and AFR-702 (25.47) on ridge, which is at par with planting chemically treated of Awassa dumme cultivar on flat land. On the other hand, the lowest pod number (10.44) was recorded on the control treatments via planting of local cultivar under farmer 
management practice. It is also reviled in this study that, higher seed per pod was recorded when of chemically treated seed of the resistant cultivar is planted on the ridges ranging 9.33 to 10.00 seed per pod, with no statistical difference among them. Though seed weight is also attributed to other genetic characteristics of the cultivar in common bean, planting of chemically treated seed of the cultivar, Awassa dumme, Omo-95 and the Local cultivar on ridges produced the highest seed weight with a value of 44.50, 45.27 and 48.27 gram respectively. On the other hand, the lowest seed weight was recorded when the resistance cultivars are grown under farmer growing practices. The present study indicates that, when resistance varieties are combined with chemical seed treatment and cultural practice via planting on ridge improves the yield components of common bean.

Table 03: Effect of combined application of treatment on yield and yield component of common bean

\begin{tabular}{|c|c|c|c|c|c|}
\hline Cultivar & Treatments & $\begin{array}{l}\text { No pod/ } \\
\text { plant }\end{array}$ & $\begin{array}{l}\text { No Seed / } \\
\text { Pod }\end{array}$ & $\begin{array}{l}100 \text { seed } \\
\text { weight }(\mathrm{g})\end{array}$ & $\begin{array}{l}\text { Yield } \\
\text { (qt/ha) }\end{array}$ \\
\hline \multirow[t]{4}{*}{ Ibado } & Planting on ridges & $15.42^{f}$ & $6.67^{\mathrm{def}}$ & $40.10^{\text {def }}$ & $15.42^{\mathrm{fl} 2}$ \\
\hline & Chemical seed treatment & $18.30^{c}$ & $8.33^{\mathrm{bc}}$ & $39.20^{\mathrm{efg}}$ & $18.30^{\mathrm{d}}$ \\
\hline & $\begin{array}{l}\text { Planting on ridges }+ \\
\text { chemical seed treatment }\end{array}$ & $22.88^{\mathrm{b}}$ & $10.00^{\mathrm{a}}$ & $43.70^{\mathrm{bcd}}$ & $22.88^{\mathrm{b}}$ \\
\hline & Farmers practice & $12.13^{\mathrm{h}}$ & $6.33^{\text {efg }}$ & $27.70^{\mathrm{k}}$ & $12.13^{\mathrm{h}}$ \\
\hline \multirow{4}{*}{$\begin{array}{l}\text { Awassa } \\
\text { dumme }\end{array}$} & Planting on ridges & $20.33^{c}$ & $6.67^{\mathrm{def}}$ & $35.10^{\text {ghi }}$ & $20.33^{c}$ \\
\hline & Chemical seed treatment & $24.42^{\mathrm{a}}$ & $8.00^{c}$ & $37.63^{\text {efgh }}$ & $24.42^{\mathrm{a}}$ \\
\hline & $\begin{array}{l}\text { Planting on ridges }+ \\
\text { chemical seed treatment }\end{array}$ & $25.48^{\mathrm{a}}$ & $9.67^{\mathrm{a}}$ & $44.50^{\mathrm{abc}}$ & $25.48^{\mathrm{a}}$ \\
\hline & Farmers practice & $15.21^{\mathrm{f}}$ & $5.67^{\text {fgh }}$ & $30.20^{\mathrm{jk}}$ & $15.21^{\mathrm{f}}$ \\
\hline \multirow[t]{4}{*}{ Omo-95 } & Planting on ridges & $14.25 \mathrm{f}^{g}$ & $6.33^{\text {efg }}$ & $36.53^{\text {fgh }}$ & $14.25^{g f}$ \\
\hline & Chemical seed treatment & $16.93^{\mathrm{e}}$ & $7.33^{\text {cde }}$ & $40.13^{\text {def }}$ & $16.93^{\mathrm{e}}$ \\
\hline & $\begin{array}{l}\text { Planting on ridges }+ \\
\text { chemical seed treatment }\end{array}$ & $20.40^{c}$ & $9.67^{\mathrm{a}}$ & $45.27^{\mathrm{ab}}$ & $20.40^{c}$ \\
\hline & Farmers practice & $10.75^{\mathrm{i}}$ & $5.33^{\text {gh }}$ & $31.93^{\mathrm{ijk}}$ & $10.75^{\mathrm{i}}$ \\
\hline \multirow[t]{4}{*}{ AFR-702 } & Planting on ridges & $19.77^{c}$ & $6.33^{\text {efg }}$ & $33.80^{\text {hij }}$ & $19.77^{\mathrm{c}}$ \\
\hline & Chemical seed treatment & $21.82^{\mathrm{b}}$ & $7.67^{\mathrm{cd}}$ & $37.53^{\text {efgh }}$ & $21.82^{\mathrm{b}}$ \\
\hline & $\begin{array}{l}\text { Planting on ridges }+ \\
\text { chemical seed treatment }\end{array}$ & $25.47^{\mathrm{a}}$ & $9.33^{\mathrm{ab}}$ & $40.90^{\text {cde }}$ & $25.47^{\mathrm{a}}$ \\
\hline & Farmers practice & $15.23 \mathrm{f}$ & $5.67 \mathrm{fg}^{\mathrm{h}}$ & $28.47^{\mathrm{k}}$ & $15.23^{\mathrm{f}}$ \\
\hline \multirow[t]{4}{*}{ Local } & Planting on ridges & $11.71^{\text {hi }}$ & $5.00^{\mathrm{h}}$ & $36.17^{\text {fghi }}$ & $11.71^{\mathrm{hi}}$ \\
\hline & Chemical seed treatment & $13.46^{\mathrm{g}}$ & $5.00^{\mathrm{h}}$ & $38.30^{\text {efg }}$ & $13.46^{\mathrm{g}}$ \\
\hline & $\begin{array}{l}\text { Planting on ridges }+ \\
\text { chemical seed treatment }\end{array}$ & $17.90^{\text {de }}$ & $6.33^{\text {efg }}$ & $48.27^{\mathrm{a}}$ & $17.90^{\text {ed }}$ \\
\hline & Farmers practice & $10.44^{\mathrm{i}}$ & $5.00^{\mathrm{h}}$ & $33.60^{\text {hij }}$ & $10.44^{\mathrm{i}}$ \\
\hline CV (\%) & & 4.36 & 11.49 & 6.98 & 4.36 \\
\hline LSD (0.05) & & 1.27 & 1.33 & 4.32 & 1.27 \\
\hline
\end{tabular}

Values are means of three replications and means followed by the same letter do not differ significantly at $\mathrm{P}<0.05$

\section{CONCLUSION}

Currently, integrated disease management is preferred strategy because of increased understanding on residual effects of chemical on the environment as well as inefficiency of sustenance of a single alternative management option to achieve the same level of control and reliability as that of chemicals. The present study results provide empirical evidences that, use of resistant varieties supplemented with proper cultural practices and chemical seed treatment could be the best alternative options in managing common bacterial blight of bean and avoiding yield losses. Use of treated seeds of the cultivar Awassa dumme and AFR-702 with suggested cultural practice via planting on ridges is the best option for bean producers around Kaffa area to reduce the disease epidemic and to obtain high yield. Moreover, integration of host resistance and seed treatments with other cultural practices applicable in the area should be given due attention to provide other alternatives common bacterial blight management.

\section{ACKNOWLEDGMENTS}

We are grateful to Southern Agricultural Research Institute (SARI) and Bonga Agricultural Research Center (BARC) for their financial and logistic support for this study. The authors also want to extend their special heartfelt thanks to all crop protection section staffs of Bonga agriculture research center, for their eager participation in trial execution and data collection. 


\section{REFERENCES}

Abiy, T. Fekede, A. and Chemeda, F. 2006. Lowland pulse diseases research in Ethiopia. Pp 228-237 Proceedings of Food and Forage Legumes of Ethiopia: Progress and Prospects.

Ali, Kemal, A., Gemechu; K Ahmed, Seid; Malhotra, Rajendra; Beniwal, Surendra; Makkouk, Khaled; and Halila, M.H.(eds.). The workshop on Food and Forage Legume, 22-26 September 2003, Addis Ababa, Ethiopia. Sponsors: EIAR and ICARDA. International Center for Agricultural Research in the Dry Areas (ICARDA) Aleppo, Syria.

Amare, 1987. Haricot bean (Phaseolus vulgaris L.) varieties performance and recommended methods of production. pp. 229-251 In: Proceedings of the 19th National Crop Improvement Conference, Institute of Agricultural Research, Addis Ababa, Ethiopia.

Ariyaratne, H.M., Coyne D.P., Vidaver A.K., Eskridge K.M. 1998. Selection for common bacterial blight resistance in common bean: effects of multiple leaf inoculation and detached pod inoculation test. J. Amer. Soc. Hort. Sci., 123(5):864-867.

Ayele, H. 1991. Importance of haricot bean export to the Ethiopian economy. pp 31- 34 In: Research on haricot bean in Ethiopia: an assessment of status, progress, priorities and strategies, 1-3 October, 1990. Addis Ababa, Ethiopia.

Chernet, T. 2008. Land Resources and Socio-Economic Report of Bonga, Boginda, Mankira and the Surrounding Areas in Kaffa Zone, SNNPRS, Ethiopia [WWW document]. URL http://www.kafabiosphere.com/assets/content-documents/KafaLanduse-Survey- Final-Report.pdf [accessed on 13 January 2015].

CIAT (Centro International de Agricultura Tropical), 1992. Pathology in Africa. In: CIAT annual report, 1992. Cali, Colombia: CIAT bean program.

CIAT (Centro International de Agricultura Tropical), 1998. Annual report. International centre for Tropical Agriculture, CIAT, Cali, Colombia, $39 \mathrm{p}$.

Dursun A., Donmez M. F., Sahin F. 2002. Identification of resistance to common bacterial blight disease on bean genotypes grown in Turkey. Eur. J. Plant Pathol. 108: 811-813.

Ebrahim, O., Ali, A., Masoud, S. and Mohammad, R. 2009. Evaluation of common bean lines for their reaction to the common bacterial blight pathogen. Phytopathol. 48: 461-468.

Fininsa, C. 2001. Epidemiology of bean common bacterial blight and maize rust in intercropping. PhD Thesis, Swedish University of Agricultural Sciences, uppsal, Sweden.

Fourie D., 2002. Distribution and severity of bacterial diseases on dry beans (Phaseolus vulgaris L.) in South Africa. J. Phytopathol. 150: $220-226$.

International Center for Agricultural Research in the Dry Areas (ICARDA). 2006. NVRSRP/IFAD Project - Progress Report $2004-2005$.

Kidane, G. 1987. A review of bean agronomy research in semi-arid regions of Ethiopia. Pp 174-180 In: Proceedings of bean research in Eastern Africa. Mukono, Uganda, 22-25 June 1987.

Mutlu, N., P. Miklas, J. Reiser and D. Coyne, 2005. Backcross breeding for improving resistance to common bacterial blight in pint beans (Paseolus vulgaris L.). Plant Breeding, 124: 282-287.

Nzungize, J.R., Lyumugabe,F., Busogoro, J., and Baudoin, J. 2012. Pythium root rot of common bean: biology and control methods. A review. Biotechnol. Agron. Soc. Environ. 16(3): 405-413

Opio, A. F., D. J. Allen and J. M. Teri, 1996. Pathogenic variation in Xanthomonas campestris pv. phaseoli, the causal agent of common bacterial blight in Phaseolus beans. Plant Pathol., 45: 1126-1133.

Popovic, T., Starovic, M., Aleksic, G., Zivkovic, S., Josic, D., Ignjatov, M. and Milovanovic, P. 2012. Response of different beans against common bacterial blight disease caused by Xanthomonas axonopodis pv.Phaseoli. Bulg. J. Agric. Sci., 18: 701-707.

Schaad N.W., Cheong S., Tamaki S., Hatziloukas E., Panopoulos N.J. 1995. A combined biological and enzymatic amplification (bpcr) technique to detect Pseudomonas syringae pv phaseolicola in bean seed extracts. Phytopathol. 85: 243-248.

Schuster M.L. and Coyne D.P. 1981. Source of Phaseolus species resistance and leaf and pod differential reactions to common blight. Hort Sci. 18(6): 901-903.

Shtienberg, D., Vintal, H., Brener, S. and Retig, B. 2006. Rational Management of Didymella rabiei in Chickpea by integration of genotype resistance and Post infection application of fungicides. Phytopathol. 90: 834-842.

Tadesse, T., Ahmed, S., Gorfu, D., Beshir, T., Fininsa, C., Abraham, A., Ayalew, M., Tilahun, A., Abebe, F. and Meles, K. 2009. Review of research on diseases food legumes. In: Tadesse, A. (ed). Increasing crop production through improved plant protection. Volume 1. Proceeding of the $14^{\text {th }}$ annual conference of the plant protection society of Ethiopia (PPSE). 19-22 Decembers 2006, Addis Ababa, Ethiopia. PPSE and EIAR, Addis Ababa Ethiopia. 598p.

Tilahun Mola and Kifle Belachew. 2015. Effect of Weeding Time on Rice (Oryza sativa Linn) Yield and Yield Components at Kaffa, Southwest Ethiopia. Journal of Biology, Agriculture and Healthcare, 5(1): 162-167

Wheeler JB. 1969. An introduction to plant diseases. John Willey and Sons Ltd., London. 301pp.

Yu Z.H., Stall R.E. and Vellojes, C.E. 1998. Detection of genes for resistance to common bacterial blight of beans. Crop Sci. 38: 1290-1296.

$$
--0 \text {-- }
$$

